2 Birner C, Series F, Lewis K, et al. Effects of auto-servo ventilation on patients with sleep-disordered breathing, stable systolic heart failure and concomitant diastolic dysfunction: subanalysis of a randomized controlled trial. Respiration 2014; 87: 54-62.

3 Fietze I, Blau A, Glos M, et al. Bi-level positive pressure ventilation and adaptive servo ventilation in patients with heart failure and Cheyne-Stokes respiration. Sleep Med 2008; 9: 652-659.

4 Kasai T, Usui Y, Yoshioka T, et al. Effect of flow-triggered adaptive servo-ventilation compared with continuous positive airway pressure in patients with chronic heart failure with coexisting obstructive sleep apnea and CheyneStokes respiration. Circ Heart Fail 2010; 3: 140-148.

5 Pepperell JC, Maskell NA, Jones DR, et al. A randomized controlled trial of adaptive ventilation for Cheyne-Stokes breathing in heart failure. Am J Respir Crit Care Med 2003; 168: 1109-1114.

6 Randerath WJ, Nothofer G, Priegnitz C, et al. Long-term auto-servoventilation or constant positive pressure in heart failure and coexisting central with obstructive sleep apnea. Chest 2012; 142: 440-447.

7 Damy T, Margarit L, Noroc A, et al. Prognostic impact of sleep-disordered breathing and its treatment with nocturnal ventilation for chronic heart failure. Eur J Heart Fail 2012; 14: 1009-1019.

8 Jilek C, Krenn M, Sebah D, et al. Prognostic impact of sleep disordered breathing and its treatment in heart failure: an observational study. Eur J Heart Fail 2011; 13: 68-75.

\title{
Sex matters in pulmonary arterial hypertension
}

\author{
To the Editor:
}

It has been known for a while that female sex is a risk factor for pulmonary arterial hypertension (PAH), but that women with the condition survive better than men [1-3]. Further light has been shed on this paradox by the excellent meta-analysis recently reported by VeNTETUOLO et al. [4] in the European Respiratory Journal. The authors showed that female patients with idiopathic or connective tissue-associated PAH have higher cardiac output and lower pulmonary vascular resistance. The average differences in male patients were small, but sufficient to translate into a $5-8 \%$ difference in mortality. What could be the explanation of this?

Population studies have shown that female lungs differ from those of men. Women have smaller lungs, decreased maximal expiratory flow rates and lower lung diffusing capacities [5]. These sex-related differences in the respiratory system persist after adjustment for body dimensions, which has been referred to as a "dysanapsis", or unequal growth of the lung parenchyma and bronchial tree with respect to body size. However, smaller lungs at any given body size do not affect gas exchange [6] and, if anything, would increase rather than decrease pulmonary vascular resistance. The control of breathing is also different in women, with progesterone-dependent, increased peripheral chemosensitivity [7], which results in in slightly but significantly lower arterial partial pressure of carbon dioxide [8]. However, hypocapnia has been shown to be a predictor or poor survival in PAH [9]. As the prognostic impact of sex on PAH was lost after the age of 45 years, VENTETUOLO et al. [4] understandably thought of possible anti-remodelling effects of oestrogens or pro-remodelling effects of testosterone.

We previously reported exercise stress echocardiographic measurements of higher resistive vessel distensibility in healthy women compared with men, which limits the increase in pulmonary artery pressures as flow increases [10]. The difference smoothened out after the age of 45 years, very much like in the study by Ventetuolo et al. [4]. This adds argument in favour of oestrogen.

The fascinating aspect of the study by VenTUOLO et al. [4] is that beneficial effects of oestrogen seem to persist in the extensively remodelled pulmonary resistive vessels of $\mathrm{PAH}$ patients. Whether this is mechanically similar can be tested by exercise stress measurements of the pulmonary circulation and recalculation of resistive vessel distensibility from a curvilinear fit of four or five pressure-flow coordinates [11]. This can be performed noninvasively.

@ERSpublications

Pre-menopausal women with pulmonary arterial hypertension survive better than men http://ow.ly/vGL7M

Robert Naeije $^{1}$ and Michele D'Alto ${ }^{2}$

${ }^{1}$ Dept of Cardiology, Erasme Hospital, Université Libre de Bruxelles, Brussels, Belgium. ${ }^{2}$ Dept of Cardiology, Monaldi Hospital, Second University of Naples, Naples, Italy. 
Correspondence: Robert Naeije, Faculty of Medicine, Free University of Brussels, 808 Route de Lennik, Brussels, 1070 Belgium. E-mail: rnaeije@ulb.ac.be

Received: March 222014 | Accepted after revision: April 032014

Conflict of interest: None declared.

\section{References}

1 Humbert M, Sitbon O, Yaïci A, et al. Survival in incident and prevalent cohorts of patients with pulmonary arterial hypertension. Eur Respir J 2010; 36: 549-555.

2 Lee WT, Ling Y, Sheares KK, et al. Predicting survival in pulmonary arterial hypertension in the UK. Eur Respir J 2012; 40: 604-611.

3 Escribano-Subias P, Blanco I, López-Meseguer M, et al. Survival in pulmonary hypertension in Spain: insights from the Spanish registry. Eur Respir J 2012; 40: 596-603.

4 Ventetuolo CE, Praestgaard A, Palevsky HI, et al. Sex and haemodynamics in pulmonary arterial hypertension. Eur Respir J 2014; 43: 523-530.

5 Sheel AW, Guenette JA. Mechanics of breathing during exercise in men and women: sex versus body size differences? Exerc Sport Sci Rev 2008; 36: 128-134.

6 Olfert IM, Balouch J, Kleinsasser A, et al. Does gender affect human pulmonary gas exchange during exercise? J Physiol 2004; 557: 529-541.

7 Behan M, Wenninger JM. Sex steroidal hormones and respiratory control. Respir Physiol Neurobiol 2008; 164: $213-221$.

8 Klæstrup E, Trydal T, Pedersen JF, et al. Reference intervals and age and gender dependency for arterial blood gases and electrolytes in adults. Clin Chem Lab Med 2011; 49: 1495-1500.

9 Hoeper MM, Pletz MW, Golpon H, et al. Prognostic value of blood gas analyses in patients with idiopathic pulmonary arterial hypertension. Eur Respir J 2007; 29: 944-950.

10 Argiento P, Vanderpool RR, Mule M, et al. Exercise stress echocardiography of the pulmonary circulation: limits of normal and sex differences. Chest 2012; 590: 4279-4288.

11 Naeije R, Vanderpool R, Dhakal BP, et al. Exercise induced pulmonary hypertension physiological basis and methodological concerns. Am J Respir Crit Care Med 2013; 187: 576-583.

Eur Respir J 2014; 44: 553-554 | DOI: 10.1183/09031936.00054514 | Copyright @ERS 2014 